\title{
UPAYA PENINGKATAN MINAT BACA MATERI PENDIDIKAN AGAMA ISLAM MELALUI PROGRAM LITERASI SEKOLAH DI SMP UNGGULAN USWATUN HASANAH CILEGON
}

\author{
Is Nurhayati ${ }^{1}$, Ahmad Firdaus $^{2}$ \\ isnurhayati87@gmail.com ${ }^{1}$, firdaussiregar26@gmail.com²
}

\begin{abstract}
Efforts to increase interest in reading Islamic religious education materials through school literacy programs are very important for an educational process of students in the current era of globalization. With the interest in reading students can broaden broad knowledge, such as general knowledge, religion and others and with reading interest activities can also be carried out together with the school literacy program. This process can also foster students' character with reading activities because of the tendency of students towards these activities. The method used is descriptive qualitative method, research This uses purposive sampling, research steps with data collection techniques with interviews. The conclusion obtained in this study is based on the results of the author's research on "Efforts to Increase Interest in Reading Islamic Education Materials" that, Based on this it can be seen the level of interest in reading Islamic religious education materials through the school literacy program at Uswatun Hasanah SMPU greatly increased by performing stages as well as the steps and efforts of teachers in fostering a fondness for reading students at school so that the formation of attitudes that can instill confidence to read critically and be ready to face future challenges.
\end{abstract}

Keywords: Interest, Reading, literacy

\begin{abstract}
Abstrak
Upaya peningkatan minat baca materi pendidikan agama islam melalui program literasi sekolah sangatlah penting untuk sebuah proses pendidikan peserta didik di masa era globalisasi saat ini. Dengan adanya minat membaca peserta didik dapat menambah wawasan pengetahuan yang luas, seperti pengetahuan umum dan agama. Kegiatan minat baca juga dapat terlaksanakan dengan di dukung oleh program literasi sekolah. Proses ini juga bisa menumbuhkan budi pekerti peserta didik. Metode yang digunakan adalah metode kualitatif deskriptif, dalam pengambilan sampel menggunakan purposive sampling. Teknik pengumpulan data dengan wawancara terbuka. Kesimpulan yang diperoleh dalam penelitian ini bahwa tingkat minat baca materi pendidikan agama islam melalui program literasi sekolah di SMPU Uswatun Hasanah sangat meningkat dengan adanya berbagai langkah dan upaya guru dalam menumbuhkan gemar membaca peserta didik di sekolah sehingga terbentuknya sikap yang dapat menanamkan rasa percaya diri untuk membaca kritis serta siap menghadapi tantangan masa depan.
\end{abstract}

Kata kunci : Minat, Baca, Literasi. 


\section{A. PENDAhULUAN}

Manusia adalah makhluk yang cerdas ditinjau dari kecerdasan IQ, EQ dan SQ. Secara fitrahnya manusia dapat mencapai kesempurnaan ketika distimulus dengan adanya pendidikan. Pendidikan merupakan salah satu proses berkembangnya manusia dalam mengubah dirinya menjadi generasi yang lebih baik, dengan adanya pendidikan manusia dapat meningkatkan kualitas pribadinya di kehidupan masa depan.

Proses pendidikan tidak lepas dari proses membaca karena kegiatan membaca dapat menambah wawasan dari pengetahuan dan pemahaman manusia itu sendiri. Maka dari hal tersebut cara meningkatkan minat baca peserta didik dengan cara membaca, hal ini sesuai dengan ungkapan (Sri Wahyuni, 2009: 57), Kegiatan membaca adalah suatu kemampuan dasar dalam kegiatan belajar karena dalam kegiatan membaca banyak kemampuan untuk memperoleh berbagai informasi ilmu pengetahuan. Melalui kegiatan membaca juga, seseorang dapat menggali informasi, mempelajari pengetahuan, memperkaya pengalaman, memperluas wawasan, dan mengetahui segala sesuatu. (Sri Wahyuni, 2009 : 179-180).

Kegiatan minat membaca ialah suatu dorongan untuk dapat memahami satu demi satu kata dan isi yang terkandung dalam sebuah teks bacaan, sehingga seseorang dapat memahami segala sesuatu hal yang ada dalam bacaan tersebut. Selebihnya, menurut (Tampubolon, 1990), menerangkan bahwa minat membaca ialah suatu keinginan seseorang untuk dapat mengenali huruf demi huruf untuk memahami makna dari tulisan tersebut. Minat membaca adalah merupakan kemampuan seseorang dalam berkomunikasi dengan diri sendiri untuk mendapatkan pengalaman emosi akibat dari bentuk perhatian yang mendalam terhadap makna bacaan tersebut. (Dalman, 2013 : 141).

Kegiatan membaca juga menurut (Farr, 1984), menyatakan bahwa " reading is the heart of education" yang artinya membaca adalah jantungnya pendidikan. Dalam hal ini, orang yang selalu membaca, pendidikannya akan berkembang dan memiliki wawasan yang luas. Sedangkan menurut (Harjasujana dan Mulyati, 1997), membaca ialah merupakan perkembangan keterampilan seseorang yang berawal dari kata sehingga berlanjut kepada membaca kritis. (Dalman, 2013 : 5-6).

Kegiatan minat membaca adalah suatu dasar kemampuan seseorang untuk mendapatkan berbagai informasi penting, wawasan luas, pengetahuan yang mumpuni dan dapat memberikan perkembangan bagi peserta didik. Kegiatan minat membaca dalam perkembangannya membutuhkan adanya kegiatan literasi, dalam kegiatan literasi merupakan suatu proses yang dibutuhkan dalam pendidikan. Dalam praktiknya kegiatan literasi sangat dibutuhkan bagi peserta didik, dengan adanya budaya literasi yang diterapkan oleh peserta didik dalam instansi pendidikan dapat membiasakan kegiatan membaca dan menulis sehingga menambah pengetahuan tentang materi pelajaran khususnya pada mata pelajaran pendidikan agama islam. Budaya literasi harus ditanamkan dalam jiwa peserta didik dan dijalankan dengan semestinya agar terciptanya peningkatan minat baca dalam diri peserta didik.

Dengan adanya peningkatan minat baca peserta didik terhadap materi pelajaran dan khususnya pada materi pendidikan agama islam, akan mengurangi angka rendahnya 
minat membaca peserta didik di Indonesia umumnya dan khususnya di sekolah yang diteliti oleh peneliti itu sendiri, karena hal itu kita termasuk Negara yang rendah dalam minat membaca hal ini berdasarkan data yang dilaporkan oleh Bank dunia no. 16369IND, dan studi IEA (International Association for the Evaluation of Education Achievermen) di Asia Timur, melaporkan bahwa peringkat terendah membaca anakanak dipegang oleh Negara Indonesia. Indonesia menempati peringkat ke 41 dari 45 negara di dunia. (Sri Wahyuni, 2009 : 180).

Program literasi adalah suatu program yang dapat menumbuh kembangkan minat membaca peserta didik sebelum kegiatan belajar mengajar berlangsung ataupun setelahnya, bukan hanya membaca program literasi juga dapat meningkatkan minat menulis peserta didik dengan wawasan yang sangat luas serta imajinasi yang unik. Menurut Grabe \& Kaplan (1992) dan Graff (2006) menjelaskan bahwa literasi adalah kemampuan untuk membaca dan menulis, dan orang yang mampu keduanya disebut literat. (Sri Wahyuni, 2009 : 179).

Kegiatan membaca dan menulis peserta didik juga haruslah di dukung oleh gerakan literasi sekolah dan program ini juga dapat menumbuhkan budi pekerti peserta didik. GLS ialah merupakan gerakan literasi sekolah yang kegiatannya banyak dilakukan di sekolah dengan melibatkan peserta didik, pendidik dan tenaga kependidikan serta orang tua. GLS dapat di praktikkan oleh pendidik dan peserta didik ketika waktu kegiatan belajar mengajar di lingkungan sekolah. Menurut peraturan kemendikbud no.23 tahun 2015 menuangkan bahwa GLS juga dapat memperkuat tumbuh kembang budi pekerti. (Nindya Faradina, $2017: 61$ ).

Menurut Rod Welford menteri pendidikan dan kebudayaan Australia literasi adalah inti atau jantungnya kemampuan siswa untuk belajar dan berhasil dalam sekolah dan sesudahnya, jadi meskipun latar belakang siswa berdeda-beda pemerintah harus mengupayakan agar mereka semua mendapatkan tingkat literasi yang memadai untuk menghadapi tantangan. Tanpa kemampuan literasi yang memadai maka siswa tidak akan dapat menghadapi tantangan-tantangan intinya kemampuan literasi adalah modal utama bagi generasi muda untuk memenangkan tantangan.

Gerakan literasi sekolah yang sudah dicanangkan Menteri Pendidikan dan Kebudayaan (Mendikbud) Republik Indoneisa 2014, Anies Baswedan, pada bulan Agustus 2015 lalu. Gerakan Literasi Sekolah diatur dalam Peraturan Menteri Pendidikan dan Kebudayaan (PERMENDIKBUD) Nomor 21 Tahun 2015. Gerakan ini bertujuan untuk memupuk kebiasaan dan motivasi membaca siswa agar mampu menumbuhkan budi pekertinya melalui buku bacaan. Tidak cukup hanya membaca, siswa juga dibiasakan untuk menulis dengan meringkas, menceritakan ulang maupun mengembangkan cerita yang akan mengasah kreativitas mereka. (http://digilib.uinsby.ac.id/21146/5/bab\%202.pdf ).

Gerakan Literasi Sekolah merupakan sebuah upaya yang dilakukan secara menyeluruh untuk menjadikan sekolah sebagai organisasi pembelajar yang warganya literat sepanjang hayat melalui pelibatan publik. Pelaksanaan Gerakan Literasi Sekolah melibatkan berbagai pihak di berbagai tingkatan mulai dari pemangku kepentingan di 
tingkat pusat, daerah, satuan pendidikan sampai masyarakat. Tiap pihak yang terlibat dalam pelaksanaan gerakan ini.

Literasi lebih dari sekadar membaca dan menulis, namun mencakup keterampilan berpikir menggunakan sumber-sumber pengetahuan dalam bentuk cetak, visual, digital, dan auditori. Literasi yang komprehensif dan saling terkait ini memampukan seseorang untuk berkontribusi kepada masyarakatnya sesuai dengan kompetensi dan perannya sebagai warga negara global. (http://katadisla.blogspot.com, 2016/11).

Program literasi merupakan suatu kegiatan yang sangat diperlukan untuk menarik minat membaca dan menulis peserta didik di suatu intansi pendidikan, dengan program literasi peserta didik dapat meningkatkan wawasan membacanya dan mampu melatih pikiran peserta didik agar memliki budi pekerti melalui program literasi dengan menggunakan sarana prasarana yang tersedia pada instansi seperti : perpustakaan, pojok bacaan dikelas, dan teknologi yang mendukung minat baca dan program literasi serta dapat menghadapai segala tantangan di masa mendatang. GLS juga dapat memberikan penerus bangsa yang mumpuni dari segala wawasan membaca dan menulis, program ini harus ditanamkan dalam jiwa peserta didik sejak dini.

Berdasarkan latar belakang masalah yang telah dikemukakan di atas, dapat rumusan masalah dalam penelitian ini sebagai berikut :

1. Bagaimana minat baca materi pendidikan agama Islam di SMPU Uswatun Hasanah?

2. Bagaimana program literasi sekolah di SMPU Uswatun Hasanah ?

3. Bagaimana upaya peningkatan minat baca materi pendidikan agama Islam melalui program literasi sekolah di SMPU Uswatun Hasanah?

\section{B. METODE}

Metode yang digunakan dalam penelitian ini adalah penelitian jenis kualitatif (Qualitative research), yaitu suatu penelitian yang ditujukan untuk mendeskripsikan dan menganalisis fenomena, peristiwa, aktifitas sosial, sikap, kepercayaan, persepsi, pemikiran orang secara individual maupun kelompok. (Nana Syaodih Sukmadinata, 2005:60).

Teknik sampel penelitian ini menggunakan purposive sampling. Teknik Purposive sampling adalah suatu teknik pengambilan sumber data dengan pertimbangan tertentu. (Sugiyono, 2017 : 301). Adapun kriteria atau pertimbangan sampel dalam penelitian ini terdiri dari tiga kriteria yaitu peserta didik yang sering membaca, peserta didik yang jarang membaca dan peserta didik yang tidak pernah membaca serta guru pendidikan agama islam di sekolah SMPU Uswatun Hasanah. Metode pengumpulan data menggunakan wawancara terbuka agar tujuan peneliti dalam meneliti kegiatan dapat secara real yang di rasakan oleh peserta didik. Menurut Creswell (2012), metode wawancara yaitu suatu kegiatan penelitian yang dilakukan oleh peneliti dengan cara merekam jawaban atas pertanyaan yang diberikan kepada responden dengan menggunakan pedoman wawancara. Sedangkan menurut Larry Cristensen (2004) bahwa wawancara merupakan sebuah teknik pengumpulan data dengan mengajukan suatu 
pertanyaan kepada yang diwawancarai (Sugiyono, 2017 : 188). Jumlah sampel yang di interview sebanyak 20 peserta didik.

Penelitian ini menggunakan teknik analisis data sebagai berikut: tahap pertama reduksi data (data reduction) data yang telah direduksi akan memberikan gambaran yang lebih jelas dan mempermudah peneliti untuk melakukan pengumpulan data. Tahap kedua penyajian data (data display) dan tahap ketiga Kesimpulan dan Verifikasi (Conclusion Drawing and Verification).

\section{HASIL DAN PEMBAHASAN}

\section{Hasil}

\section{Deskripsi dan Analisis Peningkatan Minat Baca Materi Pendidikan Agama} Islam

Berdasarkan penelitian tentang upaya peningkatan minat baca materi PAI melalui program literasi sekolah di SMPU Uswatun Hasanah dengan melakukan wawancara kepada informan yaitu guru PAI dan peserta didik kelas VII sebagai berikut :

\section{a. Peningkatan Minat Baca Materi PAI Di SMPU Uswatun Hasanah}

Kegiatan minat baca di SMPU Uswatun Hasanah adalah kegiatan yang memang harus dilakukan oleh setiap peserta didiknya agar kelak peserta didiknya dapat mengetahui dengan wawasan yang sangat luas tentang ilmu pengetahuan umum dan agama serta dapat bersaing di kehidupan mendatang. Peningkatan minat baca peserta didik di SMPU Uswatun Hasanah mulai meningkat sejak di berlakukannya kegiatan literasi di sekolahnya yang dilakukan sebelum dan sesudah kegiatan belajar mengajar berlangsung.

Kegiatan minat membaca di SMPU Uswatun Hasanah juga meningkat dengan adanya langkah-langkah yang di lakukan oleh seluruh guru yakni dengan membiasakan peserta didik untuk membaca buku bacaan atau buku pelajaran, memberikan waktu atau jadwal untuk kegiatan membaca yakni kegiatan literasi serta memfasilitasi dengan sarana prasana buku bacaan yang mendukung untuk peserta didik dan buku yang dapat di pahami oleh peserta didik itu sendiri.(Aan Niswati,S.Pd.I, guru PAI, wawancara Rabu, 18 September 2020 : Di dalam perpustakaan sekolah).

Sejalan dengan yang di nyatakan oleh beberapa para ahli bahwa, seorang sarjana pernah mengatakan bahwa orang yang minat membaca tentang ilmu pengetahuan dan memahaminya dengan baik adalah orang yang biasanya dapat berfikir baik, dia memiliki sebuah dasar pendapat dan suatu cara untuk mempertimbangkan apa yang orang lain katakan menurut pendapatnya, sebaliknya jika orang tersebut hanya membaca saja dengan tidak memahami apalagi membaca bacaan yang bukan ilmu pengetahuan seperti koran harian, bacaan komik, dan bacaan biasanya tidak sanggup untuk ikut serta dalam suatu percakapan atau perdebatan ilmiah. Hidup mereka terbuang dengan sia-sia begitu saja. 
Kegiatan minat membaca sangatlah penting sehingga perlu langkahlangkah dalam meningkatkan minat membaca antara lain sebagai berikut :

\section{1) Menyediakan waktu untuk membaca}

Alasan yang sangat umum kita dengar untuk tidak membaca adalah kekurangan waktu atau waktu yang sangat sibuk. Memang tidak bisa kita pungkiri bahwa banyak tuntutan terhadap waktu kita, tetapi jika kita berminat pada kemajuan pribadi diri kita atau diri pribadi peserta didik seorang guru harus dapat memberikan waktu bagi peserta didik untuk membaca. Dengan menyediakan waktu bagi peserta didik untuk membaca mereka akan mendapatkan informasi-informasi baru serta wawasan yang luas bagi pengetahuannya serta mempermudah bagi peserta didik untuk menyelesaikan tugas-tugas sekolahnya dengan mudah serta menumbuh kembangkan minat membaca peserta didik.

\section{2) Memilih bacaan yang baik}

Menyediakan waktu untuk membaca sangat erat berhubungan dengan salah satu aspek yang paling penting dari membaca kritis yaitu mengetahui yang baik dan bermanfaat untuk dibaca melalui buku bacaan. Setiap pribadi peserta didik harus mengadakan prinsip-prinsip yang dapat membimbing diri pribadinya dalam kegiatan minat membaca. Membaca buku bidang ilmu pengetahuan dan bidang agama yang dapat meningkatkan perilaku baik peserta didik serta menumbuhkan budi pekerti peserta didik.(Tarigan H.G, 2015 : 105-107).

Menurut hasil wawancara kepada salah seorang peserta didik mengenai peningkatan minat baca materi pendidikan agama islam bahwa, pada awalnya sebagian peserta didik di SMPU Uswatun Hasanah menganggap kegiatan membaca itu adalah suatu hal yang membosankan dan sangat menyita waktu dengan terbuang sia-sia, akan tetapi setelah berjalannya waktu ternyata kegiatan membaca sangatlah mengasikkan, menyenangkan serta dapat memberikan dorongan kepada kita untuk terus membenah diri agar budi pekerti kita menjadi lebih baik lagi dan juga dapat menumbuhkan kebiasaan membaca. Dari kegiatan membaca juga kita mendapatkan banyak informasi-informasi baru, wawasan pengetahuan dan ilmu pengetahuan yang belum kita dapatkan dari kegiatan belajar mengajar di kelas terlebih tentang ilmu pendidikan agama islam yang memang harus kita pelajari dengan sepenuhnya baik secara materi ataupun pelaksanaannya di setiap atau segala aktivitas kita sehari-hari.(Farakh Fauziah Azmy, siswi kelas VII A, wawancara Rabu, 18 September 2020 : depan perpustakaan sekolah).

Sejalan dengan beberapa peserta didik yang lain juga mereka senang dengan kegiatan membaca karena menurut mereka kegiatan membaca dapat memberikan mereka wawasan ilmu pengetahuan serta imajinasi yang sangat tinggi dan dapat lebih mengetahui berbagai informasi baru yang mereka dapatkan dan juga mereka mengatakan bahwa dari kegiatan membaca juga mereka dapat mengetahui segala sesuatu hal yang awalnya mereka tidak ketahui 
dan bisa mereka ketahui melalui membaca. Mereka juga banyak membaca buku bacaan seperti buku tentang ilmu pengetahuan umum, agama, kisah-kisah nabi, fabel, novel remaja, komik serta buku-buku yang relevan yang dapat memacu mereka untuk terus minat dan senang dalam membaca. (Rudi VII A, wawancara Jum'at, 20 September 2020 : perpustakaan sekolah).

Adapula sedikit peserta didik yang tidak gemar atau senang membaca karena mereka mempunyai alasan tertentu seperti yang dikatakan bahwa membaca adalah hal yang membosankan, membaca hal yang membuat mereka pusing, membaca membuat mereka menjadi ada batas waktu bermain. Namun dengan adanya kegiatan membaca dan gerakan literasi sekolah mereka jadi sadar akan pentingnya membaca dengan demikian mereka kini sedang berproses untuk senang dalam membaca mereka juga lebih senang membaca tentang buku yang bergambar seperti: komik, majalah, buku dongeng dan buku yang membuat mereka senang terhadap membaca, tak lupa pula mereka sesekali membaca buku tentang materi pendidikan agama islam untuk menambah wawasan tentang pendidikan agama islam seperti : tuntunan sholat, buku fiqih dan buku sejarah islam. (Pandu, Daffa, \& Abi, siswa kelas VII A, wawancara Jum'at, 20 Sepetember 2020 : perpustakaan sekolah).

Peningkatan minat baca peserta didik di SMPU Uswatun Hasanah terbukti adanya karena sekolah dan guru memberikan dan membiasakan waktu untuk peserta didiknya melakukan kegiatan membaca serta terdapat buku bacaan yang mendukung kegiatan peserta didik di sekolah tersebut. Kegiatan membaca juga dapat meningkat dengan di barengi oleh program literasi sekolah yang selama ini kementerian pendidikan dan budaya sudah mengesahkan program literasi sekolah tersebut melalui gerakan literasi sekolah. Oleh karena itu program literasi sekolah sangatlah penting bagi keberlangsungan kegiatan membaca peserta didik.

\section{b. Program Literasi Sekolah Di SMPU Uswatun Hasanah}

Progam literasi sekolah merupakan suatu sistem yang dapat memberikan dorongan bagi peserta didik untuk dapat menumbuhkan dan meningkatkan dalam kegiatan membaca dan menulis serta memiliki budaya literasi dalam diri peserta didik, sehingga dapat menumbuhkan budi pekerti peserta didik kelak dan dapat memberikan wawasan yang luas bagi peserta didik. Program literasi juga dapat memberikan perkembangan pada peserta didik yang dapat meliputi segala aspek kehidupan yang mereka jalani di masa mendatang.(Aan Niswati,S.Pd.I, guru PAI, wawancara Rabu, 18 September 2020 : di dalam perpustakaan sekolah).

Menurut hasil wawancara kepada peserta didik bahwa, program literasi sekolah di SMPU Uswatun Hasanah ialah suatu program yang sudah biasa dilakukan oleh seluruh peserta didik dalam kegiatan membaca sebelum dan sesudah belajar karena dengan adanya program tersebut kami sebagai peserta didik terbantu dengan informasi baru dan wawasan ilmu pengetahuan terlebih khusus dalam ilmu pendidikan agama islam yang kami dapatkan dari kegiatan 
membaca melalui program literasi tersebut, dan dapat meningkatkan minat kami untuk terus membaca di setiap saatnya tidak hanya di dapatkan dari guru saja ketika kegiatan belajar mengajar kami juga bisa mendapatkan dari kegiatan membaca tersebut. ( Heisya Rahma El Hani, Siswi kelas VII B, wawancara Rabu, 18 September 2020 : di dalam kelas).

Program literasi sekolah di SMPU Uswatun Hasanah dilaksanakan setiap sebelum dan sesudah kegiatan belajar mengajar setiap pelajarannya ingin berlangsung terlebih khususnya pada mata pelajaran pendidikan agama islam. Program literasi sekolah pada mata pelajaran dilaksanakan sebelum jam belajar dimulai dan waktu yang di gunakan sekitar $10 \mathrm{~s} / \mathrm{d} 15$ menit dengan membaca buku bacaan yang dalam konteks materi pendidikan agama islam seperti : buku fiqih, buku qur'an hadist, buku aqidah, buku akhlak dan buku sejarah kebudayaan islam serta buku bacaan lainnya yang mendukung materi pendidikan agama islam. Dengan program literasi tersebut untuk menumbuhkan serta meningkatkan kualitas minat membaca peserta didik agar terbiasa serta mendapatkan informasi baru tentang materi pendidikan agama islam dan membantu proses pemahaman pembelajaran di kelas. (Aan Niswati,S.Pd.I, guru PAI, wawancara Rabu, 18 September 2020 : di dalam perpustakaan sekolah).

Menurut Suragangga (2017) menyatakan bahwa, dalam pelaksanaan program literasi sekolah atau yanglebih di kenal dengan nama GLS mengacu pada beberapa prinsip : Pertama, sesuai dengan tahapan perkembangan peserta didik. Kedua, dilaksanakan dengan menggunakan berbagai macam teks dan metode. Ketiga, dilaksanakan secara terintegrasi dan holistic di semua area kurikulum. Keempat, dilakukan dengan cara berkelanjutan. Kelima, melibatkan kecakapan berkomunikasi lisan. Keenam, dapat mempertimbangkan keberagaman antar peserta didik. (Wanelly Widya, 2019:112).

Sesuai yang dikatakan oleh guru PAI SMPU Uswatun Hasanah tentang waktu pelaksanaan program literasi dan pengetahuan tentang literasi sekolah, peserta didikpun berpendapat, program literasi adalah suatu program yang dapat memproses kegiatan membaca di sekolah tersebut serta dapat mendorong peserta didik untuk minat terhadap membaca, menulis dan mengembangkan potensi berfikir peserta didik akan ilmu pengetahuan dan informasi yang mereka dapatkan dari buku bacaan. Selain itu peserta didik juga dapat memahami isi teks bacaan, mengetahui amanat isi bacaan dan segala hal yang baru mereka dapat ketahui dari kegiatan membaca melalui program literasi sekolah itu. Mereka juga berpendapat bahwa pelaksanaan literasi sekolah dilaksanakan pada waktu tertentu yaitu setelah kegiatan belajar mengajar berlangsung dan biasanya dilakukan kurang lebih $10 \mathrm{~s} / \mathrm{d} 15$ menit dan dilakukan di setiap ruangan seperti : perpustakaan sekolah, koridor sekolah, pojok bacaan, mushola, dan di tempat yang menunjang kesenangan peserta didik dalam kegiatan membaca. (Ani kelas VII B, wawancara Jum'at, 20 September 2020 : perpustakaan sekolah).

Dengan demikian program literasi sekolah di SMPU Uswatun Hasanah sangat berguna bagi tumbuh kembangnya wawasan pengetahuan serta 
menambah informasi-informasi baru yang penting bagi peserta didik sehingga peserta didik dapat menjadi pemuda yang siap dalam menghadapi tantangan di masa mendatang dengan bermodalkan wawasan yang luas, ilmu pengetahuan, serta informasi baru yang didapatkan untuk landasan dalam memberikan kritik dan saran bagi orang lain dan dengan kegigihan, kecenderungan, kesenangan dan gairah peserta didik dalam kegiatan membaca melalui program literasi sekolah.

\section{c. Upaya Peningkatan Minat Baca Materi Pendidikan Agama Islam Melalui Program Literasi Sekolah Di SMPU Uswatun Hasanah.}

Upaya peningkatan minat baca materi pendidikan agama islam melalui program literasi sekolah di SMPU Uswatun Hasanah menggunakan beberapa proses yang dapat menumbuhkan dan meningkatkan minat baca peserta didik di antaranya sebagai berikut :

1) Menciptakan suasana yang menyenangkan hati peserta didik. Guru dapat memberikan suasana hati peserta didiknya dengan senang agar peserta didik berminat dalam membaca dari diri pribadi peserta didik.

2) Memicu rasa ingin tahu peserta didik terhadap ilmu pengetahuan. Guru harus memberikan stimulus kepada peserta didik untuk dapat menumbuhkan rasa ingin tahu peserta didik terhadap informasi-informasi baru yang belum didapatkannya.

3) Menyiapkan tempat membaca yang menyenangkan, nyaman dan bersih lagi indah bagi peserta didik. Guru harus dapat menyediakan tempat baca yang menyenangkan hati dan kenyamanan peserta didik setiap saat peserta didik ingin membaca.

4) Menyediakan buku bacaan yang sangat berpengaruh atau dengan kata lain buku bacaan yang relevan dan dapat menunjang informasi tentang ilmu pengetahuan untuk di kelas. Guru harus dapat mempersiapkan buku-buku bacaan yang relevan sesuai yang dibutuhkan oleh peserta didik dalam proses pembelajaran.

5) Memasukkan program literasi sekolah ke dalam jadwal pelajaran pada setiap pelajaran yang akan di ajarkan terlebih pada kegiatan membaca materi pendidikan agama islam. Guru harus menjadwalkan program literasi sekolah dalam kegiatan belajar mengajar di sekolah.

6) Mengadakan pojok bacaan di dalam kelas agar mempermudah peserta didik untuk kegiatan membaca. Guru harus menyediakan pojok bacaan di dalam kelas agar peserta didik terbiasa dalam kegiatan membaca dikelas.

7) Mengadakan kunjungan ke perpustakaan sekolah dengan waktu atau jadwal yang telah ditentukan. Penjaga perpustakaan memberikan jadwal kunjungan ke perpustakaan untuk setiap kelas agar terbiasa dalam membaca sesuai jadwal yang ditentukan. (Aan Niswati,S.Pd.I, guru PAI, wawancara Rabu, 18 September 2020 : di depan perpustakaan sekolah).

Berdasarkan hasil wawancara di atas dapat diketahui bahwa upaya seorang guru dalam meningkatkan minat baca peserta didik melalui program 
literasi sekolah sudah baik dan dapat memberikan nilai moral serta menumbuhkan sikap keingin tahuan peserta didik terhadap informasi-informasi baru yang peserta didik dapatkan melalui membaca. Usaha yang perlu dilakukan juga untuk meningkatkan minat membaca peserta didik menurut Hasyim ialah setiap peserta didik di anjurkan memiliki perpustakaan sederhana di rumahnya. Sehingga perpustakaan dapat dijadikan tempat yang menyenangkan ketika berkumpul bersama keluarganya, sedangkan untuk meningkatkan minat membaca peserta didik di sekolah dapat diatasi dengan perbaikan dan pembenahan perpustakaan sekolah agar seluruh peserta didik lebih senang mengunjungi perpustakaan sekolah sehingga dapat memanfaatkan waktu dengan kegiatan yang positif. (Dalman, 2013 : 144).

\section{Pembahasan}

Program literasi sekolah juga menurut PIRLS (Progress in Interntional Reading Literacy Study) menyatakan bahwa, ada yang harus di perhatikan aspekaspek yang ada di dalam kegiatan tersebut antara lain : proses pemahaman, tujuan membaca dan sikap membaca. Di dalam aspek tersebut PIRLS menyimpulkan bahwa ketiga aspek tersebut dapat memberikan efek yang sangat berpengaruh terhadap upaya peningkatan minat baca peserta didik melalui program literasi sekolah yang dapat di terapkan oleh pihak sekolah agar mencapai tujuan dan dapat membiasakan peserta didik untuk gemar, senang, ingin, dan cenderung membaca buku bacaan, buku pengetahuan, buku pelajaran, buku pengetahuan agama dan umum. Serta memberantas tingkat kerendahan minat membaca masyarakat Indonesia. (Hayat B \& Yusuf S, 2011: 87).

Usaha peningkatan minat membaca materi pendidikan agama Islam melalui program literasi sekolah juga lebih dari sekedar kegiatan membaca dan menulis peserta didik, namun dapat mencakup keterampilan berfikir peserta didik menggunakan sumber-sumber pengetahuan dalam bentuk cetak, visual, digital dan audio. Upaya yang memang harus ada dalam kegiatan minat baca melalui program literasi sekolah antara lain :

a. Tahap pertama kegiatan pembiasaan membaca yang menyenangkan di ekosistem sekolah. Pembiasaan ini dapat bertujuan untuk menumbuhkan minat peserta didik terhadap kegiatan membaca dalam diri pribadi peserta didik serta memberikan pengembangan diri dalam kemampuan berliterasi di sekolah.

b. Tahan kedua menurut Anderson \& Krathwol (2001) menyatakan bahwa, kegiatan pengembangan minat membaca untuk dapat meningkatkan kemampuan peserta didik dalam berliterasi serta memahami bacaan dan mengaitkannya dengan pengalaman pribadi, berfikir kritis, dan mengolah kemampuan komunikasi secara kreatif melalui kegiatan menanggapi bacaan pengayaan.

c. Tahap ketiga menurut Anderson \& Krathwol (2001) berpendapat bahwa, kegiatan pelaksanaan pembelajaran berbasis literasi. Kegiatan ini bertujuan untuk mengembangkan kemampuan memahami teks dan mengaitkannya dengan pengalaman pribadi, berfikir kritis, dan mengolah kemampuan komunikasi 
secara kreatif melalui kegiatan menanggapi teks buku bacaan pengayaan dan buku pelajaran lainnya terlebih dalam materi pendidikan agama islam.(Teguh Mulyo, 2017: 86).

Guru di SMPU Uswatun Hasanah juga mengikuti tahapan tersebut agar teciptanya kegiatan membaca melalui program literasi sekolah dengan baik dan tersusun rapih sehingga guru dapat melihat tingkat minat membaca peserta didik melalui ketiga tahapannya dan melaksanakannya sesuai aturan. Guru juga berupaya untuk selalu mengawasi kegiatan membaca peserta didik agar dapat mengetahui buku bacaan yang di bacanya serta membimbing dengan usaha dan langkah-langkah yang cocok untuk peserta didiknya di sekolah. (Aan Niswati,S.Pd.I, guru PAI, wawancara Rabu, 18 September 2020 : di depan perpustakaan sekolah).

Sesuai dengan yang dikatakan oleh beberapa siswa tentang upaya peningkatn minat baca melalui program literasi sekolah bahwa, guru di SMPU Uswatun Hasanah telah melakukan banyak upaya untuk meningkatkan minat baca peserta didiknya melalui beberapa tahapan yang sesuai untuk peserta didiknya, kami sebagai peserta didik sangat beruntung sekolah di SMPU Uswatun Hasanah karena setelah kami sekolah di sini kami senang membaca dan lebih mengetahui informasiinformasi baru serta mendapat wawasan pengetahuan yang luas terlebih dalam pengetahuan ilmu agama, kami juga dapat merasakan pengaruh dari membaca karena memahami dengan sepenuhnya teks bacaan tersebut. Dengan kegiatan tersebut kami dapat mendapatkan yang tadi dikatakan oleh rekan-rekan saya. (Alif, Muamar, Nabila, Alena, siswa-siswi kelas VII A\&B, wawancara Rabu, 18 September 2019 : di depan kelas VII B ).

Beberapa peserta didik juga berpendapat bahwa setelah mereka senang dengan kegiatan membaca di sekolah yang melalui program literasi sekolah mereka merasakan adanya peningkatan sehingga mereka merasa bahwa kegiatan membaca adalah salah satu kegiatan yang menyenangkan, menggairahkan, menambah wawasan mereka, menumbuhkan minat baca, meingkatkan minat baca mereka, kegiatan membaca dan menulis menjadi kebiasaan yang baik serta mengetahui materi-materi pendidikan agama islam yang jauh lebih baik lagi untuk kehidupan masa mendatang. Mereka juga dapat berimajinasi serta siap untuk menghadapi tantangan masa depan karena mereka sudah memiliki bekal kemampuan serta wawasan dari ilmu pengetahuan yang mereka dapatkan dari kegiatan membaca melalui program literasi sekolah. (Bagas kelas VII B, wawancara Jum'at, 20 September 2020 : perustakaan sekolah).

Berdasarkan hal tersebut dapat diketahui tingkat minat baca materi pendidikan agama islam melalui program literasi sekolah di SMPU Uswatun Hasanah sangat meningkat dengan melakukan tahapan serta langkah dan upaya guru dalam menumbuhkan gemar membaca peserta didik di sekolah sehingga terbentuknya sikap yang dapat menanamkan rasa percaya diri untuk membaca kritis serta siap menghadapi tantangan masa depan. Sehingga terjadi perubahan kerah yang diharapkan bersama yaitu membuahkan generasi yang berkualitas. 


\section{SIMPULAN}

1. Minat baca materi PAI di SMPU Uswatun Hasanah sudah banyak peningkatan dengan melalui langkah-langkah yang dilakukan oleh guru dan juga mendukung pembiasaan peserta didik dalam membaca dengan memfasilitasi buku bacaan yang relevan dan sesuai untuk peserta didik sehingga peserta didik menjadi senang membaca.

2. Program literasi sekolah di SMPU Uswatun Hasanah sudah terbiasa dan termasuk program yang dilaksanakan setiap harinya agar dapat memberikan dorongan bagi peserta didik untuk dapat menumbuhkan dan meningkatkan minat baca peserta didik serta menumbuhkan budi pekerti dan memberi wawasan pengetahuan umum, agama dan informasi-informasi baru setelah melakukan kegiatan literasi sekolah.

3. Upaya peningkatan minat baca materi Pendidikan Agama Islam melalui program literasi sekolah di SMPU Uswatun Hasanah yaitu dengan menciptakan suasana yang menyenangkan, memicu rasa ingin tahu, menyiapkan tempat membaca yang nyaman, menyediakan buku bacaan yang relevan, memasukkan program literasi sekolah, mengadakan pojok bacaan di dalam kelas, dan mengadakan kunjungan ke perpustakaan sekolah.

\section{DAFTAR PUSTAKA}

Dalman. 2014. Keterampilan Membaca. Jakarta: Rajawali Pers.

Mulyo Teguh, E-Jurnal, Gerakan Literasi Sekolah Vol. 15, No.4, 2013.

Nana Syaodih Sukmadinata. 2005. Metode Penelitian Pendidikan. Bandung: Remaja Rosda Karya.

Nindya Faradina, Jurnal Hanata Widya, e-jurnal, Pengaruh Program Gerakan Literasi Sekolah Terhadap Minat Baca Siswa Di Sdit Muhammadiyah Annajah, Vol.6, No.8, 2017

Sri Wahyuni,e-jurnal, Menumbuh kembangkan Minat Baca Menuju Masyarakat Literat, Vol.16, No.2, 2009.

Sugiyono. 2017. Metode Penelitian Kombinasi (Mixed Methods). Bandung : Alfabeta.

Undang-Undang Republik Indonesia. 2003. Sistem Pendidikan Nasional, No.20, Bab.V, Pasal 12.

Widya Wanelly, E-Jurnal, Implementasi Kebajikan Gerakan Literasi Sekolah Dalam Rangka Menumbuhkan Minat Baca Siswa Di Sekolah Dasar, Vol.3, No.2 : 2019.

http://katadisla.blogspot.com, 2016/11 (Diakses pada tanggal 9 September 2020, pukul 13.00 WIB)

http://digilib.uinsby.ac.id/21146/5/Bab\%202.pdf (Diakses pada tanggal 9 September 2020, pukul 13.00 WIB) 